ISSN 1678-3921

Journal homepage: www.embrapa.br/pab

For manuscript submission and journal contents, access: www.scielo.br/pab

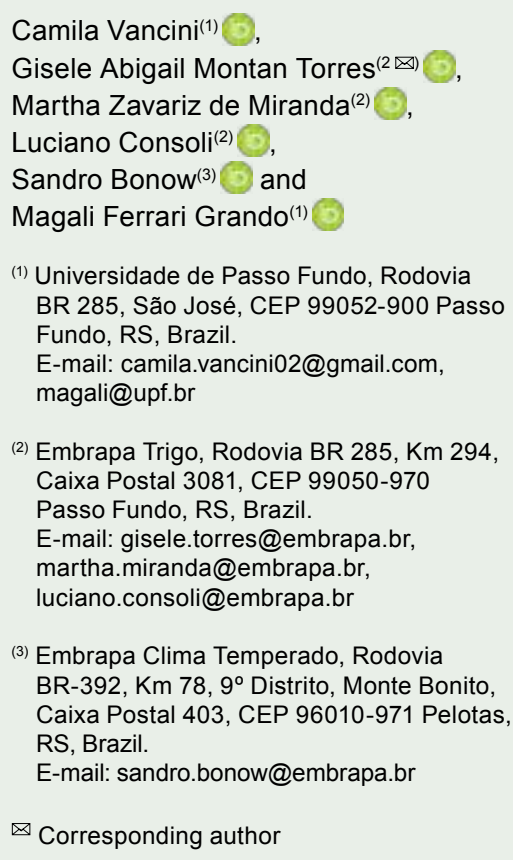

\section{Impact of high-molecular- weight glutenin alleles on wheat technological quality}

\begin{abstract}
The objective of this work was to determine high-molecular-weight glutenin subunits (HMW-GS) and their relationship with technological quality parameters in a collection of wheat (Triticum aestivum) genotypes. Two hundred and seventy-two accessions were evaluated on SDS-Page, and molecular markers were used to identify the 7oe allele and 1BL.1RS translocation. For 219 accessions with a homogenous glutenin profile, 53 profiles and 21 alleles were identified. The most frequent combination was $2 * / 7+9 / 5+10(11.9 \%)$. The mean value of genetic diversity for the three assessed Glu-1 loci was 0.67 . Based on the HMW-GS profile and on the presence of the 1BL.1RS translocation, the Glu-1 score was calculated and its correlation with technological quality parameters was analyzed. The main effects of the Glu-1 loci and of the 1BL.1RS translocation were estimated. The Glu-1 score showed a significant positive correlation with sedimentation volume, gluten strength, dough tenacity, dough extensibility, elasticity index, grain hardness index, and farinograph stability, with values between 0.23 and 0.51 . The accessions with the $1,7 \mathrm{oe}+8$, and $5+10$ alleles showed the highest values for gluten strength and farinograph stability. The score of the Glu-Al alleles should be adjusted to Brazilian wheat genotypes and cultivation conditions.
\end{abstract}

Index terms: Triticum aestivum, bread-making quality, Glu-1 score, gluten strength, HMW-GS.

\section{Impacto dos alelos de gluteninas de alto peso molecular sobre a qualidade tecnológica de trigo}

Resumo - O objetivo deste trabalho foi determinar as subunidades de gluteninas de alto peso molecular(HMW-GS) e a sua relação com os parâmetros de qualidade tecnológica em uma coleção de genótipos de trigo (Triticum aestivum). Foram avaliados 272 acessos em SDS-Page, e empregados marcadores moleculares para identificação do alelo 7oe e da translocação 1BL.1RS. Para 219 acessos com perfil de gluteninas homogêneo, foram identificados 53 perfis e 21 alelos. A combinação mais frequente foi $2 * / 7+9 / 5+10$ (11,9\%). A média de diversidade genética para os três locos $G l u-1$ avaliados foi de 0,67 . Com base no perfil de HMW-GS e na presença da translocação 1BL.1RS, foi calculado o escore Glu1 e analisada sua correlação com os parâmetros de qualidade tecnológica. Os efeitos principais dos locos Glu-1 e da translocação 1BL.1RS foram estimados. O escore Glu-1 mostrou correlação positiva significativa com volume de sedimentação, força de glúten, tenacidade da massa, extensibilidade da massa, índice de elasticidade, índice de dureza do grão e estabilidade, com valores entre 0,23 e 0,51 . Os acessos com os alelos $1,7 \mathrm{oe}+8$ e $5+10$ apresentaram os maiores valores para força de glúten e estabilidade. O escore dos alelos $G l u-A l$ deve ser ajustado para os genótipos e as condições de cultivo de trigo brasileiros.

Termos para indexação: Triticum aestivum, qualidade panificativa, escore Glu-1, força de glúten, HMW-GS. 


\section{Introduction}

Wheat (Triticum aestivum L.) is one of the major cereals produced worldwide, along with rice (Oryza sativa L.) and corn (Zea mays L.), and its world production was forecast to be 722 million tons in 2018 (FAO, 2018). In Brazil, the estimated production in 2017/2018 was 4.3 million tons, according to Companhia Nacional do Abastecimento (Acompanhamento..., 2018), which accounts for about 50\% of domestic consumption.

The flour made from wheat may be processed into different products especially due to its protein composition. Storage proteins represent $50 \%$ of the total protein of the grain and are classified as gliadins and glutenins, which, in turn, are classified as highmolecular-weight (HMW-GS) and low-molecularweight (LMW-GS) glutenin subunits. Variations in the composition of glutenins and gliadins affect the gluten functionality and baking properties of wheat flour (Delcour et al., 2012).

The HMW-GS play a key role in the baking process, promoting the formation of larger polymers, which are decisive for the strength and elasticity of gluten (Liu et al., 2009). These subunits are encoded by six genes located in pairs in three loci-Glu-A1, Glu-Bl, and Glu-Dl -, which follow a simple Mendelian inheritance pattern. Due to gene silencing and allelic variations, usually three to five HMW-GS occur in wheat and their composition varies between different cultivars (Rasheed et al., 2014).

The total Glu-1 score is usually used to predict flour technological quality throughout the wheat breeding process and is calculated by summing the individual scores of the identified protein alleles (Payne et al., 1987). Later adaptations for the scores of individual bands or pairs of bands were proposed by Shewry et al. (2009), and Wrigley et al. (2009) suggested the highest score of 5, specifically for $7 \mathrm{oe}+8$. It should be noted that, generally, 1 to 3 points are subtracted from the Glu-1 score if the genotype has the 1BL.1RS translocation. This translocation confers greater disease resistance and higher grain yield but it negatively affects milling quality and reduces sedimentation volume (Zhao et al., 2012).

The analysis of the allelic variation of HMW-GS can provide information on both the genetic variability of the germplasm and on the technological quality of wheat.
The objective of this work was to determine HMWGS and their relationship with technological quality parameters in a collection of wheat genotypes.

\section{Materials and Methods}

A total of 272 accessions of Triticum aestivum $\mathrm{L}$. were obtained from the wheat germplasm bank of Embrapa Trigo and analyzed in this work: 90 Brazilian accessions, 39 synthetic wheat lines from International Maize and Wheat Improvement Center (Cimmyt), and 143 accessions from 56 countries. The cultivars Chinese Spring, Hope, Neepawa, Opata 85, Sappo, and Yecora Rojo were also evaluated for the identification of Glu-1 alleles. To assess the homogeneity of the profiles of the HMW-GS, up to four grains of each accession were considered individually. For this analysis, the global profile of LMW-GS was also taken into account.

One hundred and ninety one of the wheat genotypes characterized for the glutenin profile were cultivated in three growing seasons - 2010, 2011, and 2013 -, in the municipality of Passo Fundo, in the state of Rio Grande do Sul, Brazil. Harvest was staggered according to the maturity of the accessions. One kilogram of harvested grains was assessed for technological quality parameters at the grain quality laboratory of Embrapa Trigo, also located at Passo Fundo.

The glutenins were extracted following a sequential procedure according to Singh et al. (1991). Ten microliters of extracts were applied on sodium dodecyl sulphate-polyacrylamide gel electrophoresis (SDS-Page), composed of stacking gel, with 4\% acrylamide and $0.01 \%$ bisacrylamide $(\% \mathrm{~T}=4 \%, \% \mathrm{C}$ $=0.23 \%$ ), and of separation gel, with $11 \%$ acrylamide and $0.08 \%$ bisacrylamide $(\% \mathrm{~T}=11 \%, \% \mathrm{C}=0.75 \%)$. Electrophoresis was performed for 6 hours at $20 \mathrm{~mA} /$ gel. The gels were stained in the Coomassie Brilliant Blue R-250 (0.02\% in 10\% trichloroacetic acid) and Coomassie Brilliant Blue G-250 $\left(0.2 \%\right.$ in $2 \mathrm{~N} \mathrm{H}_{2} \mathrm{SO}_{4}$, $1 \mathrm{~N} \mathrm{KOH}$, and $12 \%$ trichloroacetic acid) solutions. After discoloration, scanned images of the gels were obtained by the GS- 800 Calibrated Densitometer (Bio-Rad Laboratories, Hercules, CA, USA). The analysis of the images was done using the Quantity One 1-D Analysis Software, version 4.6.1 (Bio-Rad Laboratories, Hercules, CA, USA). The profiles of the HMW-GS were determined based on the nomenclature system described in Payne \& Lawrence (1983). 
Allele frequencies for the three Glu-1 loci were calculated for the accessions that presented homogeneous and unambiguous glutenin composition. The genetic diversity of each locus was obtained according to $\mathrm{Nei}$ (1973), using the equation $\mathrm{H}=1-\sum \mathrm{p}_{\mathrm{i}}{ }^{2}$, where $\mathrm{H}$ is the genetic variation index of Nei, and pi is the frequency of an allele in a given locus.

Leaves $(\sim 40 \mathrm{mg})$ were collected from all genotypes for wheat DNA extraction using a cetyltrimethylammonium bromide-based protocol buffer (Doyle \& Doyle, 1987). Samples were immersed in the extraction buffer using a $1.2-\mathrm{mL} 96$ round deep well plate and were triturated with three $2.3-\mathrm{mm}$ diameter stainless steel beads in a Mini-BeadBeater-96 (BioSpec Products, Inc., Bartlesville, OK, USA). After quantification using the Quant-iT PicoGreen dsDNA Assay Kit (Thermo Fisher Scientific, Waltham, MA, USA), 100 ng DNA were used for polymerase chain reaction (PCR), in order to identify allele 7oe from the Glu-Bl locus by a co-dominant sequence-tagged site marker (Butow et al., 2004), as well as the presence of the 1BL.1RS translocation by the competitive allelespecific PCR assay (Rasheed et al., 2016).

The Glu-1 score was calculated according to Shewry et al. (2009), and a score 5 was given for the combination 7oe +8 (Wrigley et al., 2009). The presence of the 1BL.1RS translocation was taken into account, and, if the score value was between 3 and 4, between 5 and 7, or between 8 and 10, one, two, or three points were subtracted from the score.

Physicochemical and rheological analyzes were carried out to determine the technological profile of each wheat genotype. For this, the following methods approved by American Association of Cereal Chemists International (AACC International, 2010) were adopted: method 55-31.01, single-kernel characterization system for wheat kernel texture, using the 4100 Single-Kernel Characterization System (Perten Instruments, Springfield, IL, USA) to obtain the grain hardness index (GHI); method 46-13.01, grain crude protein content (GPC), by the NIRS XDS equipment (FOSS NIRSystems, Hillerod, Denmark); method 56-81.03, determination of grain falling number, based on the ability of alpha-amylase to liquefy a starch gel, using the FN 1800 instrument (Perten Instruments, Springfield, IL, USA); method 26-70.01, milling test to obtain wheat flour with the Quadrumat Senior (Brabender, Duisburg, Germany); method $38-12.02$, wet gluten content, obtained with the 2100
Glutomatic System (Perten Instruments, Springfield, IL, USA); method 54-30.02, using the alveoConsistograph NG equipment (Chopin Technologies, Villeneuve-la-Garenne, France) to test dough strength, tenacity, extensibility, tenacity/extensibility ratio, and elasticity index; and method 54-60.01, using the Typ 820600 farinograph equipment (Brabender, Duisburg, Germany) to obtain the stability parameter. Sedimentation volume (SV) in SDS was determined as described by Pena et al. (1990).

The relationship between technological quality parameters and the Glu-l score values was evaluated by Pearson's correlation analysis. The Box-Cox approach was used to transform data for gluten strength, dough tenacity, and dough tenacity/extensibility ratio, as well as for GPC, GHI, and farinograph stability, when they did not present normal distribution. The main effects of the different subunits for the Glu-Al, Glu-Bl, and Glu-D1 loci and the 1BL.1RS translocation were estimated using the restricted maximum likelihood algorithm from the Genstat, version 19, statistical package (Payne et al., 2011). The effects of year and the loci $\mathrm{x}$ year interaction were also determined. The experimental design was completely randomized with an unbalanced number of replicates.

\section{Results and Discussion}

Of the 272 accessions evaluated, 226 (83.1\%) presented HMW-GS and LMW-GS with profile homogeneity when grains of different plants were considered. For seven of them, which are synthetic wheat lines from Cimmyt, the designation of the Glu-D1 alleles is not clear. The reason are the new alleles derived from the diploid-related DD genome species used for the production of synthetic wheat lines and that have not been recorded yet.

Of the accessions, 219 - 66 from Brazil, 32 synthetic wheat lines, and 121 from different countries - were considered homogenous for the glutenin profile and with an unambiguous designation of alleles, totaling 53 different profiles and 21 alleles. These results express the variability of $G l u-1$ alleles in the studied collection. Three alleles were identified in the Glu-A1 locus: $47 \%$ with the $2 *$ subunit, $34.2 \%$ with the null allele, and $18.7 \%$ with the allele 1 . Allele $2^{*}$ has the highest Glu-1 score among the other Glu-Al alleles (Shewry et al., 2009) and its predominance can reflect selection preference during the breeding process. 
However, a relatively high percentage of accessions showed the null allele, which is associated with poor baking quality. A study by Sanchez-Garcia et al. (2015) with landraces and modern Spanish wheat varieties revealed the tendency of the frequency of the null allele to decrease with time. For the Glu-Bl locus, nine alleles were identified, and the most frequent was $7+9$ $(28.8 \%)$ and $7+8(26.5 \%)$. The use of a DNA marker made it possible to distinguish the seven and 7 oe alleles, which could not be differentiated in SDS-Page. According to Cooper et al. (2016), the over-expression of the 7oe allele and a higher protein accumulation have shown to have a positive influence on wheat enduse quality. Furthermore, of the 219 accessions, 15 had the combination $7 \mathrm{oe}+8$ (with score 5), and 7 presented 7oe alone. In locus Glu-Dl, nine allele combinations were identified. The predominant combinations were $2+12(53.9 \%)$ and $5+10(35.6 \%)$. In the collection as a whole, the most frequent Glu-1 allelic combination observed was $2 * / 7+9 / 5+10(11.9 \%)$.

The mean value of the genetic diversity of the 219 accessions evaluated for the three Glu-1 loci was 0.67 (Table 1). This value is higher than that obtained for 200 French (0.57) and 119 Argentine (0.59) wheat cultivars, which were assessed considering Glu-3 and Glu-1 loci diversity (Branlard et al., 2003; Lerner et al., 2009). Individually, genetic diversity was $0.63,0.81$, and 0.58 for $G l u-A 1, G l u-B 1$, and $G l u-D 1$, respectively (Table 1). The synthetic wheat lines from Cimmyt presented greater genetic diversity in the Glu-Dl locus (0.84), followed by the Glu-B1 (0.68) and Glu-A1 (0.30) loci; the higher diversity in the Glu-Dl locus is generally reported for diploid wheat-related species used for synthetic production. In the other accessions, the greatest diversity was found in the Glu-Bl locus, followed by the Glu-Al and Glu-DI loci.
As previously observed for wheat produced in different countries, the Glu-1 score corrected for the presence of the 1BL.1RS translocation had a positive correlation of $0.36(\mathrm{p} \leq 0.001)$ with SV (Table 2). Although this value is lower than that of 0.52 obtained in a research with only 16 lineages (Costa et al., 2013), the present study is the first known analyses with such a wide collection of wheat produced in Brazil. There was a positive correlation $(\mathrm{p} \leq 0.001)$ of $0.51,0.32,0.27$, 0.49 , and 0.39 between the Glu- 1 score and gluten strength, dough tenacity, dough extensibility, the elasticity index, and farinograph stability, respectively (Table 2), which are among the most important properties of gluten, mainly regarding its breadmaking quality.

In Brazil, the indicative commercial classification of wheat cultivars takes into account the parameters gluten strength and farinograph stability (Brasil, $2010)$, which presented a correlation $(\mathrm{p} \leq 0.001)$ of 0.51 and 0.39 , respectively, with the Glu-1 score (Table 2). It should be pointed out that, despite their significance, for gluten strength, this value is lower than the 0.88 cited by Payne et al. (1988), whereas, for farinograph stability, Costa et al. (2017) did not find correlation with the Glu-1 score. In addition, correlation values for other parameters of technological quality were even lower, although also significant (i.e., $\mathrm{SV}=0.36, \mathrm{P}=0.32$, $\mathrm{L}=0.27$, and $\mathrm{GHI}=0.23$ ). These results show that, specifically for Brazil, the score used individually for the prediction of bread-making quality is not the most suitable, since the weight of each allele in the Glu-1 score was estimated based on foreign wheat genotypes evaluated mostly in the Northern Hemisphere.

The wheat genotypes were pooled according to the allelic composition in the Glu-1 loci. The Glu-1 loci had a significant effect on SV, gluten strength, dough tenacity, elasticity index, GPC, GHI, wet gluten content,

Table 1. Number of alleles and genetic diversity of high-molecular-weight glutenin subunits of wheat (Triticum aestivum) genotypes.

\begin{tabular}{|c|c|c|c|c|c|c|c|c|}
\hline \multirow[t]{2}{*}{ Number of accessions } & \multicolumn{2}{|c|}{$G l u-A 1$} & \multicolumn{2}{|c|}{$G l u-B 1$} & \multicolumn{2}{|c|}{$G l u-D 1$} & \multicolumn{2}{|c|}{ Glu-1 } \\
\hline & $\begin{array}{c}\text { Number of } \\
\text { alleles }\end{array}$ & $\begin{array}{l}\text { Genetic } \\
\text { diversity }\end{array}$ & $\begin{array}{c}\text { Number of } \\
\text { alleles }\end{array}$ & $\begin{array}{l}\text { Genetic } \\
\text { diversity }\end{array}$ & $\begin{array}{c}\text { Number of } \\
\text { alleles }\end{array}$ & $\begin{array}{l}\text { Genetic } \\
\text { diversity }\end{array}$ & $\begin{array}{c}\text { Number of } \\
\text { alleles }\end{array}$ & $\begin{array}{l}\text { Genetic } \\
\text { diversity }\end{array}$ \\
\hline 219 with a homogeneous profile & 3 & 0.63 & 9 & 0.81 & 9 & 0.58 & 21 & 0.67 \\
\hline 66 from Brazil & 3 & 0.48 & 7 & 0.79 & 2 & 0.44 & 12 & 0.57 \\
\hline 32 synthetic wheat lines & 2 & 0.30 & 7 & 0.68 & 8 & 0.84 & 17 & 0.61 \\
\hline 121 from other countries & 3 & 0.65 & 8 & 0.76 & 3 & 0.50 & 14 & 0.64 \\
\hline
\end{tabular}

Pesq. agropec. bras., Brasília, v.54, e00639, 2019

DOI: 10.1590/S1678-3921.pab2019.v54.00639 
and farinograph stability (Table 3), confirming the effect of loci on quality parameters. The effect of year was significant for all parameters of technological quality.

Wheat genotypes with the 1BL.1RS translocation presented a lower mean for SV, gluten strength, dough extensibility, falling number, and wet gluten content (Table 4). The decrease in rheological parameters is a consequence of the loss of the LMW-GS encoded by the Glu-B3 locus located on the short arm of chromosome 1B (Gobaa et al., 2008), explaining the weight of the 1BL.1RS translocation in the calculation of the Glu-1 score. It is assumed that the effects of this translocation are much more pronounced, the greater the intrinsic quality of the material.

Table 2. Pearson's correlation between the Glu-1 score, sedimentation volume, and parameters of wheat (Triticum aestivum) technological quality ${ }^{(1)}$.

\begin{tabular}{|c|c|c|c|c|c|c|c|c|c|c|c|c|}
\hline & Glu-1 score & SV & $\mathrm{W}$ & $\mathrm{P}$ & $\mathrm{L}$ & $\mathrm{P} / \mathrm{L}$ & EI & GPC & FN & GHI & WG & WA \\
\hline SV & $0.36^{* * *}$ & & & & & & & & & & & \\
\hline $\mathrm{W}$ & $0.51^{* * *}$ & $0.49 * * *$ & & & & & & & & & & \\
\hline $\mathrm{P}$ & $0.32 * *$ & $0.32 * * *$ & $0.78 * * *$ & & & & & & & & & \\
\hline $\mathrm{L}$ & $0.27 * * *$ & $0.33^{* * *}$ & $0.24 * *$ & $-0.24 * *$ & & & & & & & & \\
\hline $\mathrm{P} / \mathrm{L}$ & 0.05 & -0.01 & $0.32 * * *$ & $0.79 * * *$ & $-0.68 * * *$ & & & & & & & \\
\hline EI & $0.49 * * *$ & $0.37 * * *$ & $0.79 * * *$ & $0.41 * * *$ & $0.21 * *$ & 0.08 & & & & & & \\
\hline GPC & -0.07 & $0.19^{*}$ & -0.06 & -0.04 & 0.10 & -0.06 & $-0.16^{*}$ & & & & & \\
\hline $\mathrm{FN}$ & 0.06 & $0.13^{*}$ & $0.11 *$ & $0.15^{* * *}$ & -0.09 & $0.16^{*}$ & 0.0 & 0.14 & & & & \\
\hline GHI & $0.23^{* *}$ & $0.24 * * *$ & $0.48^{* * *}$ & $0.62 * * *$ & -0.11 & $0.45^{* * *}$ & 0.15 & -0.09 & $0.20 * * *$ & & & \\
\hline WG & -0.11 & $0.21 * * *$ & -0.06 & 0 & 0.14 & -0.05 & $-0.29 * * *$ & $0.79 * * *$ & $0.13^{*}$ & 0.13 & & \\
\hline WA & 0.03 & $0.29 * * *$ & $0.36^{* * *}$ & $0.65 * * *$ & $-0.14 *$ & $0.52 * * *$ & -0.13 & $0.19 * *$ & $0.16^{*}$ & $0.70^{* * *}$ & $0.38^{* * *}$ & \\
\hline FS & $0.39 * * *$ & $0.39 * * *$ & $0.71^{* * *}$ & $0.39^{* * *}$ & $0.27 * * *$ & 0.06 & $0.75 * * *$ & -0.06 & 0.07 & $0.17^{* *}$ & $-0.17^{*}$ & 0.01 \\
\hline
\end{tabular}

(1)SV, sedimentation volume; W, dough strength; P, dough tenacity; L, dough extensibility; P/L, dough tenacity/extensibility ratio; EI, elasticity index; GPC, grain protein content; FN, falling number; GHI, grain hardness index; WG, wet gluten content; WA, water absorption; and FS, farinograph stability. $* * *$, and $* * *$ Significant correlations at $5.0,1.0$, and $0.1 \%$ probability, respectively.

Table 3. General linear model solution for fixed effects of loci, year, and loci x year interaction on parameters of wheat (Triticum aestivum) technological quality ${ }^{(1)}$.

\begin{tabular}{|c|c|c|c|c|c|c|c|c|c|c|c|c|c|}
\hline & DF & SV & $\mathrm{W}^{(2)}$ & $\mathrm{P}^{(2)}$ & $\mathrm{L}$ & $\mathrm{P} / \mathrm{L}^{(2)}$ & EI & $\mathrm{GPC}^{(2)}$ & $\mathrm{FN}$ & $\mathrm{GHI}^{(2)}$ & WG & WA & $\mathrm{FS}^{(2)}$ \\
\hline Glu-A1 & 2 & $21.19 * * *$ & $18.68 * * *$ & $11.98 * * *$ & 1.90 & 2.39 & $23.73 * * *$ & $13.35 * * *$ & 0.59 & $23.82 * * *$ & $13.58 * * *$ & $19.62 * * *$ & $23.94 * * *$ \\
\hline Year & 2 & - & $29.56^{* * *}$ & $89.38 * * *$ & $96.20 * * *$ & $97.63 * * *$ & $3.78^{*}$ & $11.83 * * *$ & $15.71 * * *$ & $10.18 * * *$ & $22.94 * * *$ & $85.13 * * *$ & $4.49 *$ \\
\hline $\begin{array}{l}\text { Glu-A1 x } \\
\text { year }\end{array}$ & 4 & - & 0.49 & 0.28 & 0.90 & 0.88 & 1.15 & 0.23 & $3.39 * *$ & 0.97 & 1.18 & 0.10 & 0.80 \\
\hline$G l u-B 1$ & 6 & $6.59 * * *$ & $10.16^{* * *}$ & $6.10 * * *$ & $2.93 * *$ & $2.34 *$ & $11.47 * * *$ & $6.72 * * *$ & $4.48 * * *$ & $7.01 * * *$ & $9.58 * * *$ & $2.30 *$ & $10.34 * * *$ \\
\hline Year & 2 & - & $32.25 * * *$ & $89.70 * * *$ & $96.95 * * *$ & $95.71 * * *$ & $3.14 *$ & $11.15^{* * *}$ & $15.12 * * *$ & $10.11 * * *$ & $21.76^{* * *}$ & $81.56^{* * *}$ & $6.20 * *$ \\
\hline $\begin{array}{l}\text { Glu-B1 x } \\
\text { year }\end{array}$ & 12 & - & 0.72 & 0.60 & 1.76 & 1.26 & 0.57 & 0.33 & 1.59 & 0.34 & 0.58 & 0.28 & 1.21 \\
\hline Glu-D1 & 1 & 0.17 & $67.95 * * *$ & $31.29 * * *$ & 2.72 & $21.15 * * *$ & $159.12 * * *$ & $6.48 *$ & $5.49 *$ & $22.40 * * *$ & $19.41 * * *$ & 0.09 & $76.18 * * *$ \\
\hline Year & 2 & - & $25.52 * * *$ & $79.86^{* * *}$ & $90.60 * * *$ & $93.88 * * *$ & $4.51 *$ & $7.96 * * *$ & $8.73 * * *$ & $10.70 * * *$ & $19.73 * * *$ & $71.03 * * *$ & $6.64 * * *$ \\
\hline $\begin{array}{l}G l u-D 1 \times \\
\text { year }\end{array}$ & 2 & - & $3.32 *$ & 0.07 & $7.28 * * *$ & $3.72 *$ & 1.55 & 0.48 & 1.29 & 0.33 & 0.41 & 0.07 & 0.12 \\
\hline 1BL.1RS & 1 & $13.13 * * *$ & $5.62 *$ & 0.01 & $29.83 * * *$ & $13.54 * * *$ & 0.02 & 0.06 & $11.73 * * *$ & 1.55 & $6.53 *$ & 1.89 & 0.15 \\
\hline Year & 2 & - & $27.85^{* * *}$ & $85.68 * * *$ & $100.77 * * *$ & $99.24 * * *$ & $3.55^{*}$ & $11.38 * * *$ & $15.68 * * *$ & $9.30 * * *$ & $22.32 * * *$ & $80.64 * * *$ & $4.03 *$ \\
\hline $\begin{array}{l}\text { 1BL.1RS } \\
\text { x year }\end{array}$ & 2 & - & 0.13 & 0.82 & 2.06 & 2.31 & 0.50 & 0.09 & 1.51 & 0.23 & 1.65 & 0.16 & 1.40 \\
\hline
\end{tabular}

${ }^{(1)} \mathrm{DF}$, degrees of freedom; SV, sedimentation volume; W, gluten strength; P, dough tenacity; L, dough extensibility; P/L, dough tenacity/extensibility ratio; EI, elasticity index; GPC, grain protein content; FN, falling number; GHI, grain hardness index; WG, wet gluten content; WA, water absorption; and FS, farinograph stability. ${ }^{(2)}$ The Box-Cox approach was used to transform data for W, P, P/L, GPC, GHI, and FS when they did not present normal distribution. *,** and $* * *$ Significant effects at $5.0,1.0$, and $0.1 \%$ probability, respectively. 


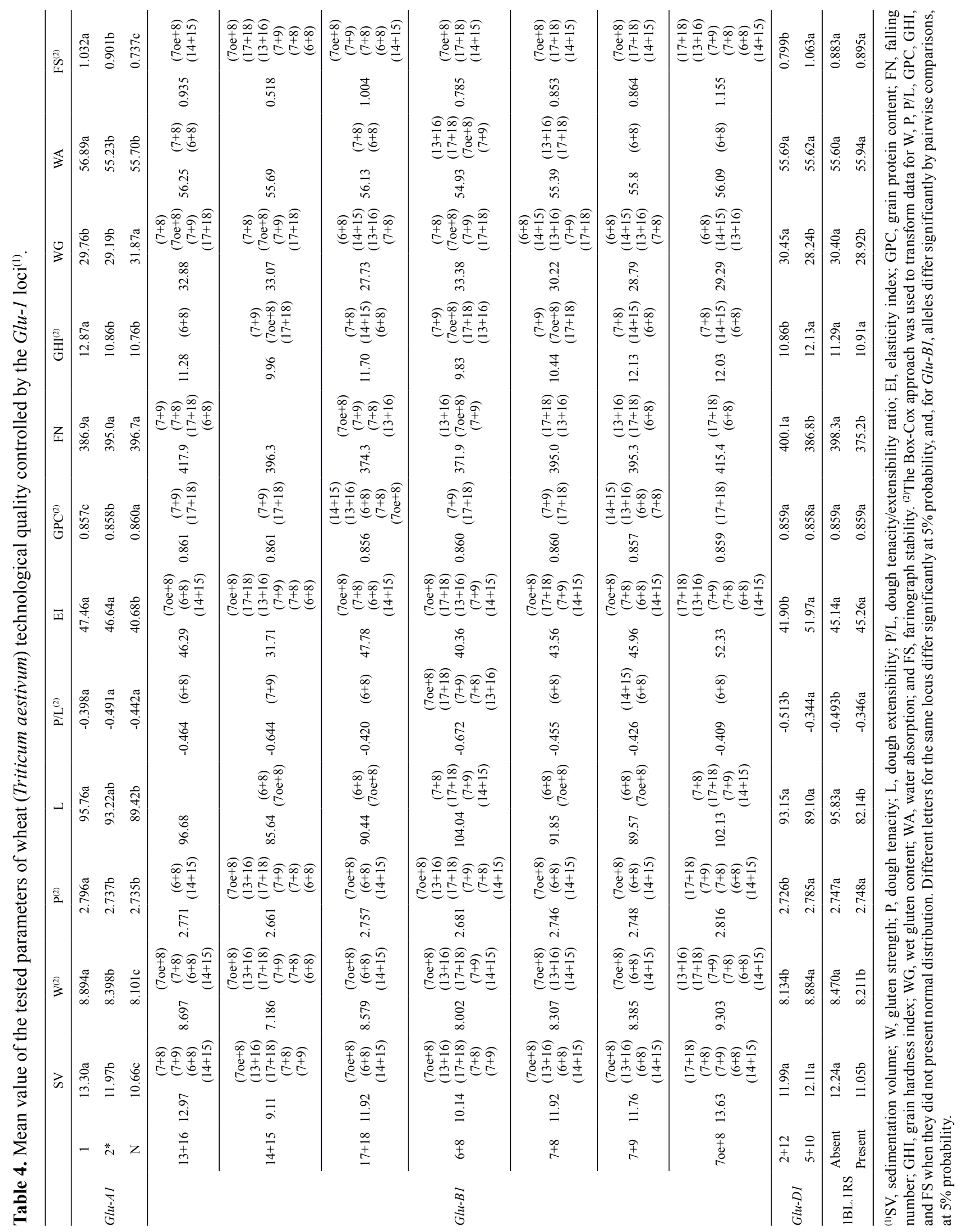


In the Glu-A1 locus, alleles 1 and $2 *$ are considered to have the same effect on wheat quality, with the same score value (Shewry et al., 2009). However, in the present study, the accessions presenting allele 1 were superior to those with the $2^{*}$ and $\mathrm{N}$ alleles regarding $\mathrm{SV}$, gluten strength, dough tenacity, GHI, water absorption, and farinograph stability (Table 4). Conversely, in 189 recombinant inbred lines assessed in the USA, dough mixing properties have been shown to be better in accessions with allele $2 *$ rather than with allele 1 (Zheng et al., 2010). This shows the importance of evaluating wheat quality properties specifically in Brazil, since the effects of each allele differ depending on the environment.

The effect of the Glu-Bl locus was significant for all quality parameters (Table 3). Accessions with the $70 e+8$ alleles presented the highest averages for gluten strength, elasticity index, and farinograph stability, differing from the others with different $G l u-B 1$ alleles, while those with alleles $14+15$ and $6+8$ showed the lowest mean values (Table 4). Cooper et al. (2016) concluded that the $70 \mathrm{o}+8$ alleles are associated with higher gluten quality and strength. These features are important for bread-making quality, which is the main industrial wheat flour application in Brazil. Diversely, in China, where $50 \%$ of the wheat flour is used for steamed bread, noodles and instant noodles, the best results for SV and farinograph stability were obtained with alleles $13+16$, which differed statistically from the other ones (Li et al., 2009) and could be used, in Brazil, to obtain different end-use products from flour.

For SV, wheat accessions with the $7+9$ alleles showed significantly higher values than those with the $6+8$ alleles (Würschum et al., 2016). The obtained results also indicate a statistical difference between alleles $7+9$ and $6+8$ for $\mathrm{SV}$, as well as for the other parameters, except dough extensibility, dough tenacity/extensibility ratio, wet gluten content, and farinograph stability. Particularly for the parameters dough tenacity and elasticity index, the higher averages of the $7+9$ alleles indicate greater dough tenacity and viscoelasticity. However, in Mexico, Liang et al. (2010) observed that lineages carrying the $7+9$ alleles had intermediate results for parameters related to gluten strength. This divergence of data shows once again that the effect of different alleles on wheat quality strictly depends on the environment.
The Glu-Dl locus had a highly significant $(p \leq 0.001)$ effect on gluten strength, dough tenacity, dough tenacity/extensibility ratio, elasticity index, GHI, wet gluten weight, and farinograph stability, besides a significant one on GPC and falling number (Table 3). For falling number and wet gluten content, the accessions with $2+12$ alleles showed a higher mean, while, for the other parameters of technological quality, the accessions with $5+10$ alleles had higher values (Table 4). These data confirm the association of the $5+10$ alleles with a better bread-making quality (Langner et al., 2017).

The obtained results are indicative that the effect of some alleles with a high or a low Glu-1 score differed. This can explain, together with the significant year effect, the lower values of the correlations between the Glu-l score and quality parameters. Therefore, it is mandatory to review the score of some alleles and to analyze the bread-making quality of wheat considering Brazilian background and environmental conditions.

\section{Conclusions}

1. The collection of evaluated wheat (Triticum aestivum) accessions presents a high genetic diversity for the Glu-1 loci.

2. The Glu-1 score shows positive correlations with sedimentation volume, gluten strength, dough tenacity, dough extensibility, elasticity index, grain hardness index, and farinograph stability.

3 . The accessions with the $1,7 \mathrm{oe}+8$, and $5+10$ alleles at the Glu-A1, Glu-B1, and Glu-D1 loci, respectively, show the highest values for gluten strength and farinograph stability, indicating the need to adjust the calculation of the score of the Glu-Al alleles for Brazilian conditions.

\section{Acknowledgments}

To Empresa Brasileira de Pesquisa Agropecuária (Embrapa), for financial support (project number 02.11.08.001.00.03.002).

\section{References}

AACC INTERNATIONAL. Approved methods of analysis. $11^{\text {th }}$ ed. St. Paul, 2010. Available at: <http://methods.aaccnet.org/toc. aspx>. Accessed on: Sept 132018. 
ACOMPANHAMENTO DA SAFRA BRASILEIRA [DE] GRÃOS: safra 2017/18: décimo segundo levantamento, v.5, n.12, set. 2018.

BRANLARD, G.; DARDEVET, M.; AMIOUR, N.; IGREJAS, G. Allelic diversity of HMW and LMW glutenin subunits and omega-gliadins in French bread wheat (Triticum aestivum L.). Genetic Resources and Crop Evolution, v.50, p.669-679, 2003. DOI: https://doi.org/10.1023/A:1025077005401.

BRASIL. Ministério da Agricultura, Pecuária e Abastecimento. Instrução Normativa $\mathrm{n}^{\mathrm{o}} 38$, de 30 de novembro de 2010. [Estabelece o Regulamento Técnico do Trigo, definindo o seu padrão oficial de classificação, com os requisitos de identidade e qualidade, a amostragem, o modo de apresentação e a marcação ou rotulagem]. Diário Oficial [da] República Federativa do Brasil, 1 dez. 2010. Seção 1, p.2-4. Available at: <http:// sistemasweb.agricultura.gov.br/sislegis/action/detalhaAto. do? method $=$ visualizarAtoPortal Mapa $\&$ chave $=358389789>$. Accessed on: Sept. 132018.

BUTOW, B.J.; GALE, K.R.; IKEA, J.; JUHÁSZ, A.; BEDÖ, Z.; TAMÁS, L.; GIANIBELLI, M.C. Dissemination of the highly expressed Bx7 glutenin subunit (Glu-Blal allele) in wheat as revealed by novel PCR markers and RP-HPLC. Theoretical and Applied Genetics, v.109, p.1525-1535, 2004. DOI: https://doi.org/10.1007/s00122-004-1776-8.

COOPER, J.K.; STROMBERGER, J.A.; MORRIS, C.F.; BAI, G.; HALEY, S.D. End-use quality and agronomic characteristics associated with the Glu-Blal high-molecular-weight glutenin allele in U.S. hard winter wheat. Crop Science, v.56, p.2348-2353, 2016. DOI: https://doi.org/10.2135/cropsci2015.10.0610.

COSTA, M.S.; SCHOLZ, M.B. dos S.; FRANCO, C.M.L. Effect of high and low molecular weight glutenin subunits, and subunits of gliadin on physicochemical parameters of different wheat genotypes. Ciência e Tecnologia de Alimentos, v.33, p.163170, 2013. Suplemento 1. DOI: https://doi.org/10.1590/S010120612013000500024.

COSTA, M.S.; SCHOLZ, M.B. dos S.; MIRANDA, M.Z.; FRANCO, C.M.L. Effect of glutenin subunits on the baking quality of Brazilian wheat genotypes. Bragantia, v.76, p.11-22, 2017. DOI: https://doi.org/10.1590/1678-4499.636.

DELCOUR, J.A.; JOYE, I.J.; PAREYT, B.; WILDERJANS, E.; BRIJS, K.; LAGRAIN, B. Wheat gluten functionality as a quality determinant in cereal-based food products. Annual Review of Food Science and Technology, v.3, p.469-492, 2012. DOI: https://doi.org/10.1146/annurev-food-022811-101303.

DOYLE, J.J.; DOYLE, J.L. A rapid DNA isolation procedure for small quantities of fresh leaf material. Phytochemical Bulletin, v.19, p.11-15, 1987.

FAO. World cereal production forecast raised slightly from July but still down sharply from last year; stocks lowered further. 2018. Available at: <http://www.fao.org/worldfoodsituation/csdb/ en>. Accessed on: Sept. 102018.

GOBAA, S.; BANCEL, E.; BRANLARD, G.; KLEIJER, G.; STAMP, P. Proteomic analysis of wheat recombinant inbred lines: variations in prolamin and dough rheology. Journal of Cereal
Science, v.47, p.610-619, 2008. DOI: https://doi.org/10.1016/j. jcs.2007.07.001.

LANGNER, M.; KRYSTKOWIAK, K.; SALMANOWICZ, B.P.; ADAMSKI, T.; KRAJEWSKI, P.; KACZMAREK, Z.; SURMA, M. The influence of Glu-1 and Glu-3 loci on dough rheology and bread-making properties in wheat (Triticum aestivum L.) doubled haploid lines. Journal of the Science of Food and Agriculture, v.97, p.5083-5091, 2017. DOI: https://doi.org/10.1002/jsfa.8385.

LERNER, S.E.; KOLMAN, M.A.; ROGERS, W.J. Quality and endosperm storage protein variation in Argentinean grown bread wheat. I. Allelic diversity and discrimination between cultivars. Journal of Cereal Science, v.49, p.337-345, 2009. DOI: https://doi.org/10.1016/j.jcs.2008.04.003.

LI, Y.; HUANG, CH.; SUI, X.; FAN, Q.; LI, G.; CHU, $X$. Genetic variation of wheat glutenin subunits between landraces and varieties and their contributions to wheat quality improvement in China. Euphytica, v.169, p.159-168, 2009. DOI: https://doi.org/10.1007/s10681-009-9905-8.

LIANG, D.; TANG, J.; PEÑA, R.J.; SINGH, R.; HE, X.; SHEN, X.; YAO, D.; XIA, X.; HE, Z. Characterization of CIMMYT bread wheats for high- and low-molecular weight glutenin subunits and other quality-related genes with SDS-Page, RP-HPLC and molecular markers. Euphytica, v.172, p.235-250, 2010. DOI: https://doi.org/10.1007/s10681-009-0054-x.

LIU, L.; WANG, A.; APPELS, R.; MA, J.; XIA, X.; LAN, P.; HE, Z.; BEKES, F.; YAN, Y.; MA, W. A MALDI-TOF based analysis of high molecular weight glutenin subunits for wheat breeding. Journal of Cereal Science, v.50, p.295-301, 2009. DOI: https://doi.org/10.1016/j.jcs.2009.05.006.

NEI, M. Analysis of gene diversity in subdivided populations. Proceedings of the National Academy of Sciences of the United States of America, v.70, p.3321-3323, 1973. DOI: https://doi.org/10.1073/pnas.70.12.3321.

PAYNE, P.I.; HOLT, L.M.; KRATTIGER, A.F.; CARRILLO, J.M. Relationships between seed quality characteristics and HMW glutenin subunit composition determined using wheats grown in Spain. Journal of Cereal Science, v.7, p.229-235, 1988. DOI: https://doi.org/10.1016/S0733-5210(88)80004-3.

PAYNE, P.I.; LAWRENCE, G.L. Catalogue of alleles for the complex gene loci, Glu-Al, Glu-B1, and Glu-Dl which code for high-molecular weight subunits of glutenin in hexaploid wheat. Cereal Research Communications, v.11, p.29-35, 1983.

PAYNE, P.I.; NIGHTINGALE, M.A.; KRATTIGER, A.F.; HOLT, L.M. The relationship between HMW glutenin subunit composition and the bread-making quality of British-grown wheat varieties. Journal of the Science of Food and Agriculture, v.40, p.51-65, 1987. DOI: https://doi.org/10.1002/jsfa.2740400108.

PAYNE, R.W.; MURRAY, D.A.; HARDING, S.A.; BAIRD, D.B.; SOUTAR, D.M. Introduction to GenStat for Windows. $14^{\text {th }}$ ed. Hertfordshire: VSN International, 2011.

PENA, R.J.; AMAYA, A.; RAJARAM, S.; MUJEEB-KAZI, A. Variation in quality characteristics associated with some spring $1 \mathrm{~B} / 1 \mathrm{R}$ translocation wheats. Journal of Cereal Science, v.12, p.105-112, 1990. DOI: https://doi.org/10.1016/S07335210(09)80092-1. 
RASHEED, A.; WEN, W.; GAO, F.; ZHAI, S.; JIN, H.; LIU, J.; GUO, Q.; ZHANG, Y.; DREISIGACKER, S.; XIA, X.; HE, $Z$. Development and validation of KASP assays for genes underpinning key economic traits in bread wheat. Theoretical and Applied Genetics, v.129, p.1843-1860, 2016. DOI: https://doi.org/10.1007/s00122-016-2743-X.

RASHEED, A.; XIA, X.; YAN, Y.; APPELS, R.; MAHMOOD, T.; HE, Z. Wheat seed storage proteins: advances in molecular genetics, diversity and breeding applications. Journal of Cereal Science, v.60, p.11-24, 2014. DOI: https://doi.org/10.1016/j. jcs.2014.01.020.

SANCHEZ-GARCIA, M.; ÁlVARO, F.; PEREMARTI, A.; MARTÍN-SÁNCHEZ, J.A.; ROYO, C. Changes in bread-making quality attributes of bread wheat varieties cultivated in Spain during the 20th century. European Journal of Agronomy, v.63, p.79-88, 2015. DOI: https://doi.org/10.1016/j.eja.2014.11.006.

SHEWRY, P.R.; D'OVIDIO, R.; LAFIANDRA, D.; JENKINS, J.A.; MILLS, E.N.C.; BÉKÉS, F. Wheat grain proteins. In: KHAN, K.; SHEWRY, P.R. (Ed.) Wheat: chemistry and technology. $4^{\text {th }}$ ed. St. Paul: AACC International, 2009. p.223-298. DOI: https://doi.org/10.1094/9781891127557.008.

SINGH, N.K.; SHEPHERD, K.W.; CORNISH, G.B. A simplified SDS-Page procedure for separating LMW subunits of glutenin.
Journal of Cereal Science, v.14, p.203-208, 1991. DOI: https://doi.org/10.1016/S0733-5210(09)80039-8.

WRIGLEY, C.; ASENSTORFER, R.; BATEY, I.; CORNISH, G.; DAY, L.; MARES, D.; MRVA, K. The biochemical and molecular basis of wheat quality. In: CARVER, B.F. (Ed.). Wheat: science and trade. Ames: Wiley-Blackwell, 2009. p.495-520. DOI: https://doi.org/10.1002/9780813818832.ch21.

WÜRSCHUM, T.; LEISER, W.L.; KAZMAN, E.; LONGIN, C.F.H. Genetic control of protein content and sedimentation volume in European winter wheat cultivars. Theoretical and Applied Genetics, v.196, p.1685-1696, 2016. DOI: https://doi.org/10.1007/s00122-016-2732-0.

ZHAO, C.; CUI, F.; WANG, X.; SHAN, S.; LI, X.; BAO, Y.; WANG, H. Effects of $1 \mathrm{BL} / 1 \mathrm{RS}$ translocation in wheat on agronomic performance and quality characteristics. Field Crops Research, v.127, p.79-84, 2012. DOI: https://doi.org/10.1016/j. fcr.2011.11.008.

ZHENG, S.; BYRNE, P.F.; HALEY, S.D.; SHAN, X.; REID, S.D. Glutenin allelic variation and 1AL.1RS effects on dough mixing properties of wheat grown in irrigated and rainfed environments. Euphytica, v.176, p.357-369, 2010. DOI: https://doi.org/10.1007/ s10681-010-0215-y. 